\title{
Importance and Applications of GIS in Engineering
}

\section{Gomasa Ramesh}

\begin{abstract}
Site selection is very important for any construction of structure and management. The appropriate site selection gives very good life and durability to the structure. Site selection is also improving quality of the structure and life of the structure. So, site selection is very important in of structures. In this, Geographic information system is a tool used for site selection of structure. Geographic information system is used to analyses and manipulate the spatially referenced data. It is also known as remotely sensed data or information. Geographic information system is giving a better output with in short period of time. So Geographic information system is most widely used now a days around the world. In recent developments attribute data are analysis by using Geographic information system. The selection of site depends on soil conditions, environmental conditions, weathering agencies etc. so proper planning and design of site selection is very important to make a structure in long life and increase the life span of the structure.
\end{abstract}

Keywords: Geographic information system, Data Base, Applications, Engineering, Components of GIS, Subsystems.

\section{INTRODUCTION}

Geographic information system is a computer-based information system. Geographic information system is used to capture, store and analyses and display spatially attributed data for solving complex problems, planning and management. Geographic information system is consisting of software and hardware as well. Geographic information system is used to collect the data and analyses data around the globe. Geographic information system is specialized data base and it records the locations of information. The word of Geographic information system has two meanings. These are earth and geographic space. The meaning of first one is subjected to earth's features and resources including the human activities. The meaning of second one is collection of data and solve the problems. Geographic information system involves color maps and images and graphs and tables and other various activities. It is mainly important for industrial site selection process. It is very effective on environmental, social and economic properties of the geographic area. One of important thing in GIS is evaluation of geo environment of industrial site selection. It is helpful for planners and designers for construction of structure. In this paper explains about importance of GISand selection of a site for construction of structures.

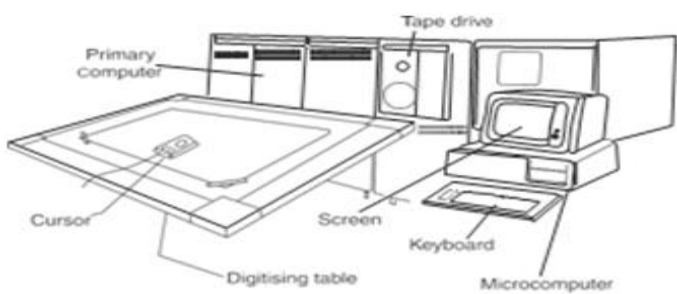

Manuscript received on 03 April 2021 | Revised Manuscript received on 23 April 2021 | Manuscript Accepted on 15 May 2021 | Manuscript published on 30 May 2021.

* Correspondence Author

Gomasa Ramesh, M.Tech Structural Engineering, Vaagdevi College of Engineering, Warangal, India.

(C) The Authors. Published by Lattice Science Publication (LSP). This is an open access article under the CC-BY-NC-ND license (http://creativecommons.org/licenses/by-nc-nd/4.0/)

\section{LITERATURE REVIEW}

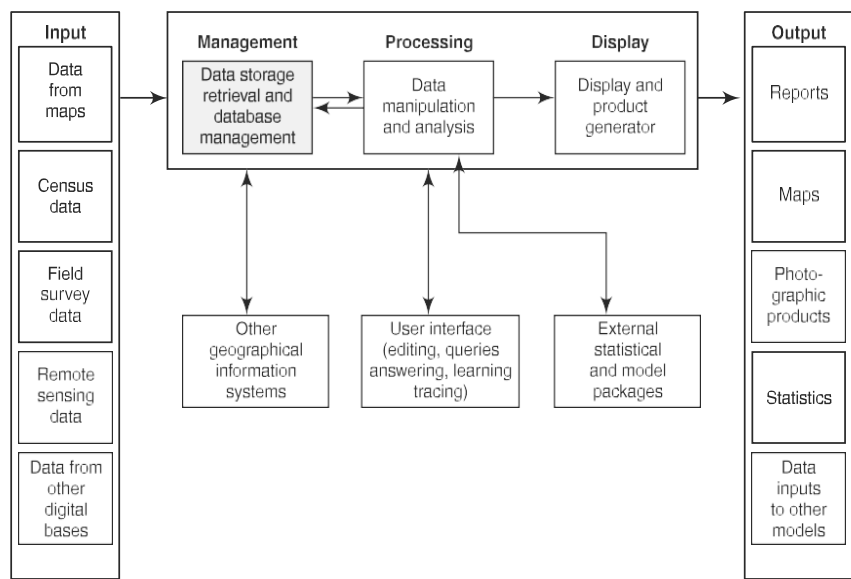

I. Fig. Components of GIS

\section{SUBSYSTEM IN GIS}

There are 3 important elements in GIS system. They are as follows;
$>$ Computer hardware
$>$ Data
$>$ Computer program
$>\mathrm{CPU}$

There are 5 important sub systems in GIS. They are as follows;

1. Input: image-based Geographic information system

2. Management: storage and management

3. Processing: data classification and manipulation

4. Display: display the results for the problem

5. Output: providing maps, images, figures, tables etc.

\section{OBJECTIVES}
$>$ To collect the data
$>$ Manipulate data
$>$ Support general research
$>$ Decision making based on spatial Data
$>$ To produce maps, images, figures etc.
$>$ Rapidly analysis and display data
$>$ Data processing and information management
$>$ Graphical output

\section{METHODOLOGY}

Data can be collected directly from the field. There are different types of data available such as captured data, encoded data, organized data. The data in GIS is classified into two types. They are spatial data and non-spatial data. Spatial data is also known as graphical data. It consists of natural features, lines etc. this data is spatially located in digital form. Non spatial data is also known as attribute data. It represents geographic regions, plans, maps, reports etc. spatial data related to nonspatial attributes.

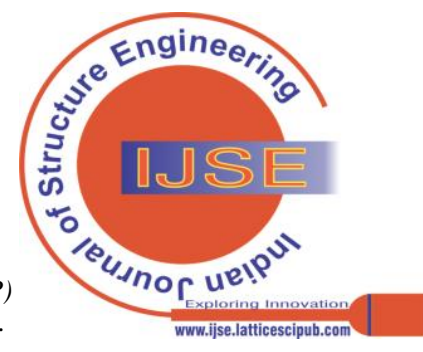




\section{Importance and Applications of GIS in Engineering}

\section{Representation of features}
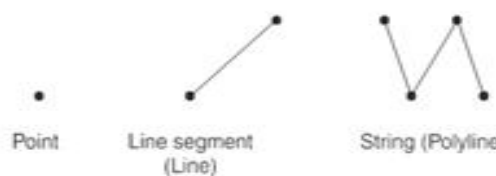

(a) Point data
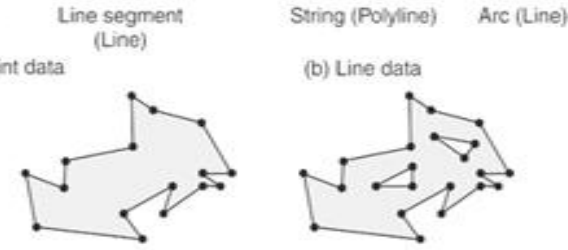

(b) Line dat

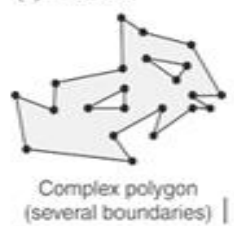

only one boundary)

(several boundaries)

(c) Areal (polygon data)

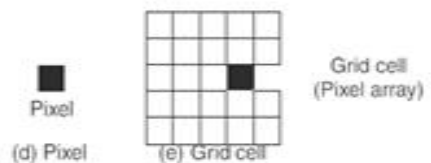

Fig. Representation of Features

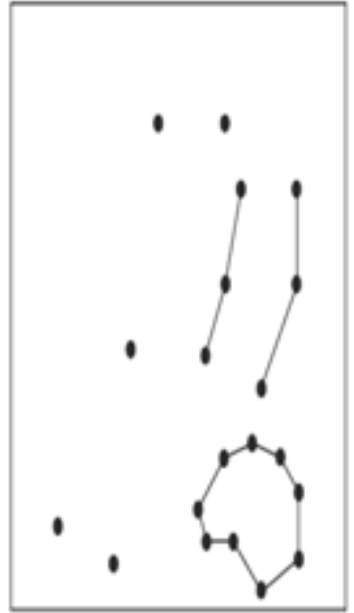

(a) Vector model

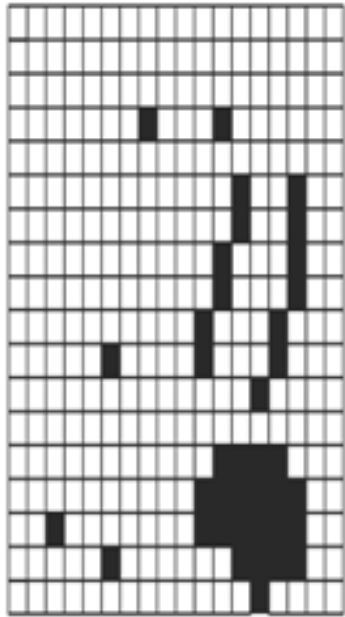

(b) Raster model
Fig. Data model

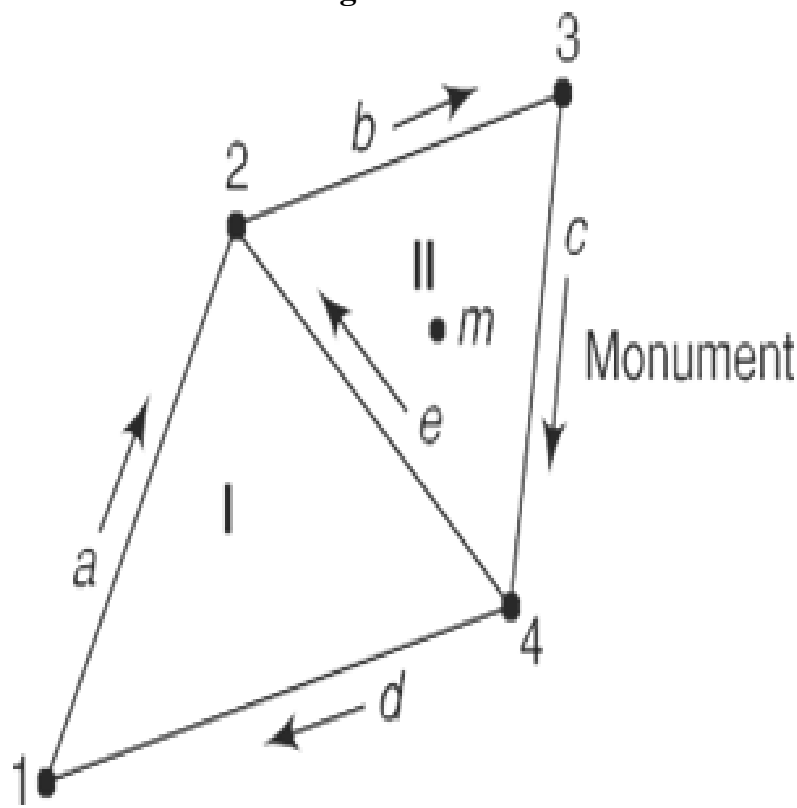

Fig. Vector representation of graphical record

\begin{tabular}{|c|c|c|c|c|c|}
\hline \multicolumn{2}{|c|}{ (i) } & \multicolumn{2}{|c|}{ (ii) } & \multicolumn{2}{|c|}{ (iii) } \\
\hline Point identifier & Coordinutes & $\begin{array}{c}\text { Line } \\
\text { identifier }\end{array}$ & Points & $\begin{array}{c}\text { Areal } \\
\text { identifier }\end{array}$ & Lines \\
\hline 1 & $\left(x_{1}, y_{1}\right)$ & $a$ & 1,2 & I & $a, e, d$ \\
\hline 2 & $\left(x_{2} y_{2}\right)$ & b & 2,3 & II & $b, c, e$ \\
\hline 3 & $\left(x_{3}, y_{3}\right)$ & c & 3,4 & & \\
\hline 4 & $\left(x_{4} y_{4}\right)$ & $d$ & 4,1 & & \\
\hline Monument, m & $\left(x_{m} y_{m}\right)$ & $\ell$ & 4,2 & & \\
\hline
\end{tabular}

Fig. Vector representation of Graphical Record

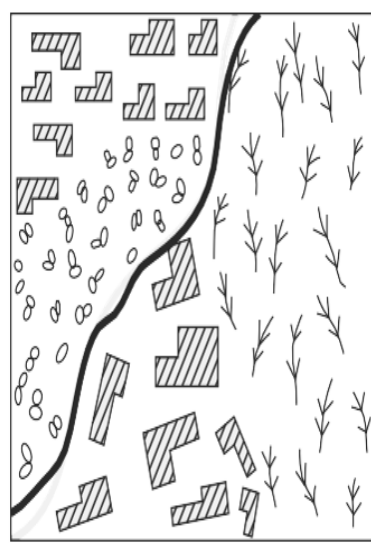

(a) Using standard topographic symbols

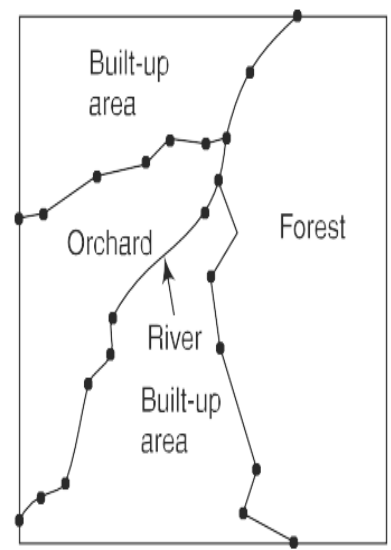

(b) Vector representation
Fig. Representation of vector data Coodnale relerence ct starting poirt of leatu'te

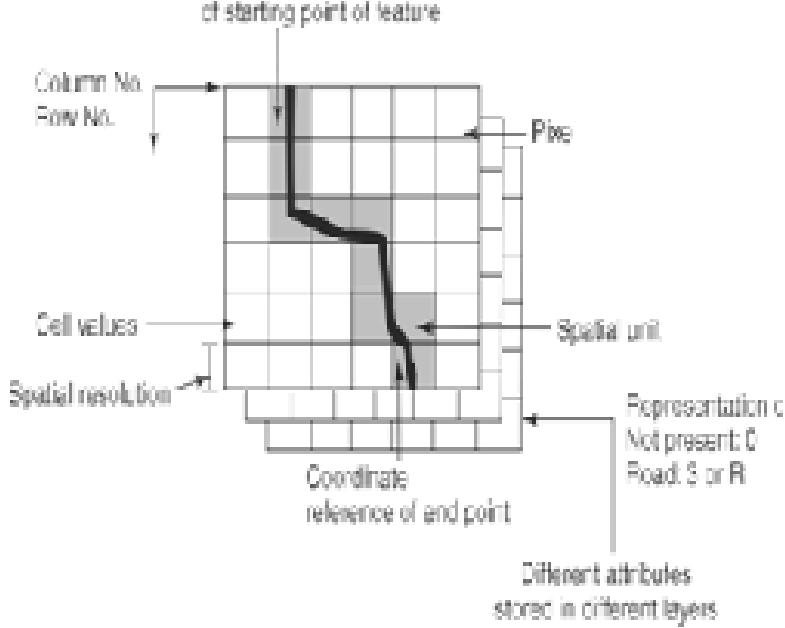

Fig. Characteristic of raster data

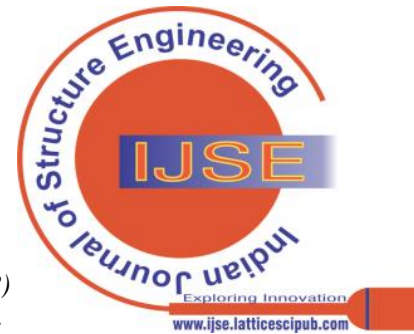




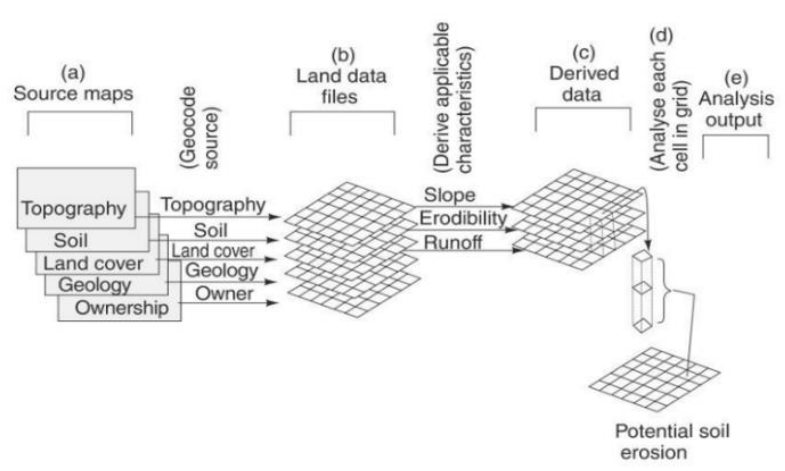

Fig. Analysis procedure of geocoded data

\section{GIS BASED MULTI CRITERIA ANALYSIS}

As we know that AHP gives the ranking to selected sites, whereas GIS gives best location among the chosen as well as particular areas which are best suited for the best location/site. This is done by GIS multi-criterion analysis which is done either by 1) Suitability analysis using raster's, identifying suitable industrial 2) Suitability analysis using Model Builder Main components of Arc GIS 1) Arc Map = Edit and create features in a feature class 2) Arc Catalog = Create feature class and to originate and manage data 3) Arc tool Box = Analyses and transform data (like in terms of raster data) 4) Arc scene $=$ View data in 3d and performs 3d analysis 5) Arc globe = View data in globe and create animation 6) Model Builder = Create geo-processing models and tool boxes. Arc Tool Box: Contains number of tools. For this operation we need only spatial analyst tool which contains reclassify, raster creation, overlay, distance tools for the performance operation.

\section{ANALYSIS TECHNIQUES FORRASTER CALCULATION:}

In this study we used many tools and analysis techniques to implement MCDA and to select the best industrial site. The process passed in the following analysis. 1. Euclidean distance analysis 2. Reclassify analysis 3. Surface analysis 4. Weighted overlay analysis 5. Model builder technique for this analysis we used the technique is Model builder technique which uses the concept of weighted average and Reclassify tools.

Data layer over a hill station as follows;

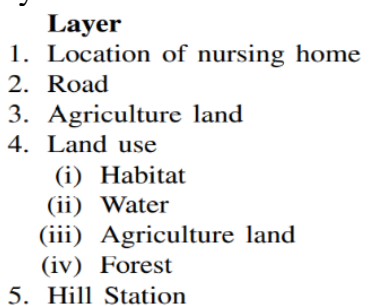

Code
1
2
3

1
2
4
5
10

GIS has been successfully applied in many fields outside of the hydrological field. However, the full capabilities of GIS for hydrological field have at to be realized. To move forward, there is a need to identify current applications of GIS concepts and technologies. To study industrial site selection that will provide comprehensive and timely information for management decision support, to review the impacts of implementing GIS on hydrological field.

Discrete entities: The space would be seen as occupied with entities that are describe by their properties and can be located on earth using coordinate system. The entities have a clear boundary. Buildings, Roads, Land parcels etc. are the example of discrete entities.

Continuous Fields: The variation of an attribute over the space as a continuous field. No physical boundary can ever be observed in such case. Temperature, Pressure, Elevation etc. across an area are the examples of continuous fields.

A city can be marked as a single point on a world map but would be marked as a polygon on a state map.

Simple features: These are easy to create, store and rendered on screen very quickly. They lack connectivity relationships and so are inefficient for modeling phenomena conceptualized as fields.

Point entities: These represent all geographical entities that are positioned by a single XY coordinate pair. Along with the XY coordinates the point must store other information such as what does the point represent etc.

Line entities: Linear features made by tracing two or more XY coordinate pair.

-Simple line: It requires a start and a point.

-Arc: A set of XY coordinate pairs describing a continues complex line. The shorter the line segment and higher the number of coordinate pairs, the close the chain approximates a complex curve.

Raster data model: Here, geographic space is represented by array of cells or pixels which are arranged in rows and columns. Each pixel has a value that represents information. A point can be represented by a single pixel in raster model. A line is a chain of spatially connected cells with the same value.

Topological features: A topology is a mathematical procedure that describes how features are spatially related and ensures data quality of the spatial relationships. Topological relationships include following three Basic elements:

-Connectivity: Information about linkages among spatial objects.

-Contiguity: Information about neighboring spatial object.

-Containment: Information about inclusion of one spatial object with in another spatial object.

Network: The topologic relationship between the features is maintained in a connectivity table. Polygons with explicit topological structures: Introducing explicit topological relationships takes care of islands as well 10 as neighbors. The topological structures are built either by creating topological links during data input or using software.

Selection process involves mainly two phases. Those are

1) Site Screening

2) Site Evaluation

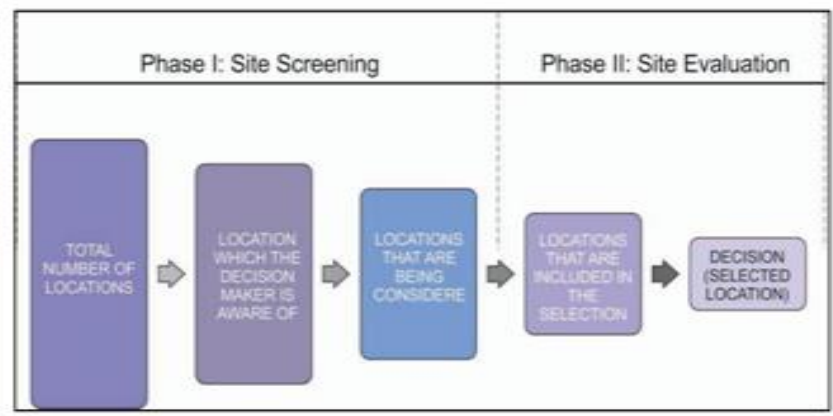

Fig. Site selection process

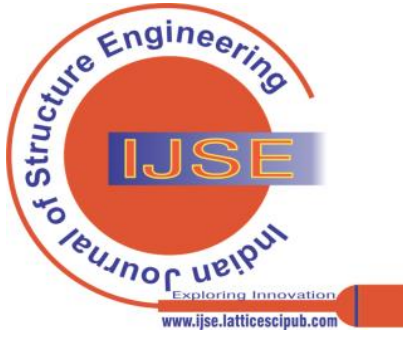




\section{Importance and Applications of GIS in Engineering}

\section{INTRODUCTION TO PRESENT INDUSTRIAL DEVELOPMENT}

The people or companies engaged in a particular kind of commercial enterprise. Industries are many types like manufacturing, metallurgical, mining, textile industries etc..... Industry is more focus on reducing the cost of production and achieving the levels of technical competence. It can stay globally relevant and deal with cutthroat competition. India has been significantly increasing its capacities to achieve self-sufficiency from an industrial point of view. Industries do work on the export and import of the materials. So, industries are very important for the economic growth. Development of industry depends on construction process and its design depends on life time of the project. So, for this site selection is very important for the industry.

\section{TESTS AND RESULTS}

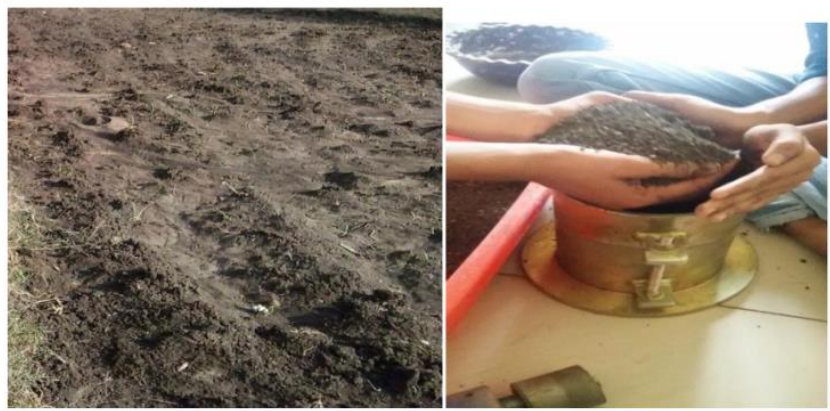

Fig. Soil and Compaction test

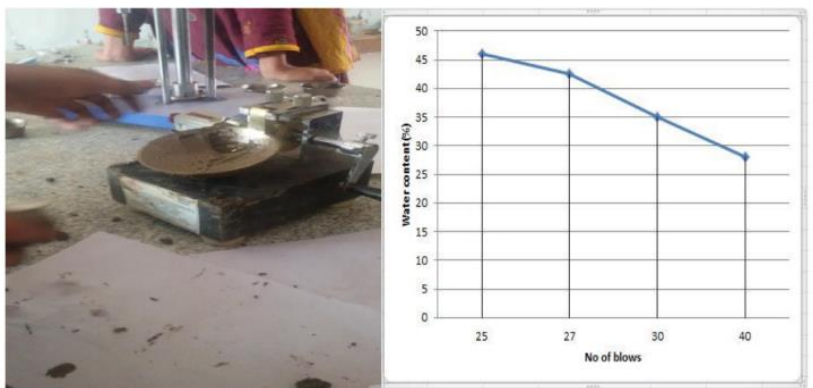

Fig. Liquid limit and optimum moisture content

\begin{tabular}{llc}
\hline S. No & Test & Characteristics \\
\hline 1 & Texture & Black cotton \\
2 & Optimum moisture content(g/cc) & 3.6 \\
3 & Plastic Limit (\%) & 38 \\
4 & Liquid Limit (\%) & 46 \\
\hline & & \\
\hline & & \\
\hline
\end{tabular}

Fig. Industrial water and alkaline test

\begin{tabular}{lll}
\hline S.No. & Test & Characteristics \\
\hline 1 & PH & 8.609 \\
2 & BOD 5 days (mg/lt) & 24 \\
3 & Alkalinity (mg/lt) & 590 \\
4 & TDS (mg/lt) & 105.4 \\
5 & EC (ms) & 7.89 \\
\hline
\end{tabular}

Chosen Sites for Industrial site selections

Mittapally is located in Dichpally Mandal, Nizamabad District having latitude 18.5936 and longitude 78. 2583.Total area of Mittapally is 868 hectares and population of 2510.

Table Geographical coordinates of Mittapally

\begin{tabular}{lll}
\hline Control points & Longitude & Latitude \\
\hline A & $78^{\circ} 14^{\prime} 30.21 " \mathrm{E}$ & $18^{\circ} 35^{\prime} 57.41 \mathrm{~N}$ \\
$\mathrm{~B}$ & $78^{\circ} 14^{\prime} 32.91^{\prime \prime} \mathrm{E}$ & $18^{\circ} 34^{\prime} 51.68^{\prime \prime N}$ \\
$\mathrm{C}$ & $78^{\circ} 16^{\prime} 33.66^{\prime \prime} \mathrm{E}$ & $18^{\circ} 34^{\prime} 49.65^{\prime \prime N}$ \\
$\mathrm{D}$ & $78^{\circ} 16^{\prime} 26.41^{\prime \prime} \mathrm{E}$ & $18^{\circ} 35^{\prime} 57.48^{\prime \prime} \mathrm{N}$ \\
\hline
\end{tabular}

\begin{tabular}{|c|c|c|c|c|}
\hline & Soil characteristics \\
\hline
\end{tabular}

\section{CONCLUSION}

Every structure before built site investigation is important. To know the properties of soil and condition of soil and environmental conditions. So, by using Geographic information system we can select a suitable site for the structures and also, we can collect the data from the area. By using this to make plans, designs and construction. This paper deals with importance of Geographic information system and uses for selection of a suitable site for the structure.

\section{ACKNOWLEDGEMENT}

This Research Paper is Dedicated to My Parents GomasaSammaiah and GomasaSammakka for always supporting and encouraging to me in hard time and also My Special thanks to My Goddess Sister Rajamani and My Loving Brother Vijay.

\section{REFERENCES}

1. H. Allcott, "Site selection bias in program evaluation," Q. J. Econ., 2015. [CrossRef]

2. Gomasa Ramesh, Dr. Annamalai Rangasamy Prakash, "Repair, Rehabilitation and Retrofitting of Reinforced Concrete Structures", Special Issue 2021, International Journal of Engineering Research \& Technology (IJERT) ISSN: 2278-0181 Published by, www.ijert.org NCACE - 2020 Conference Proceedings.

\section{Published By:}

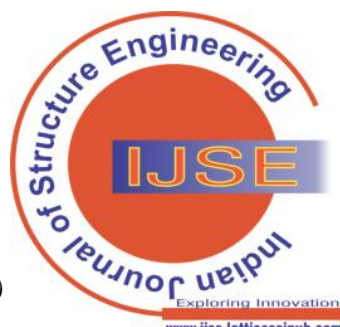


3. Dharna Ramya, Gomasa Ramesh and Dr. Annamalai Rangasamy Prakash, "Shear Behavior of Hybrid Fiber Reinforced Concrete", International Journal for Modern Trends in Science and Technology, Vol. 07, Issue 02, February 2021, pp.-79-82, DOI:10.46501/IJMTST0702013.

4. P. C. Longdill, T. R. Healy, and K. P. Black, "An integrated GIS approach for sustainable aquaculture management area site selection," Ocean Coast. Manag., 2008. [CrossRef]

5. Gomasa Ramesh, Dharna Ramya, Mandala Sheshu Kumar; "Health Monitoring of Structures by Using Non-Destructive Testing Methods", International Journal of Advances in Engineering and Management (IJAEM) Volume 2, Issue 2, pp: 652-654, DOI:10.35629/5252-45122323

6. J. M. Sánchez-Lozano, C. Henggeler Antunes, M. S. García-Cascales, and L. C. Dias, "GIS-based photovoltaic solar farms site selection using ELECTRE-TRI: Evaluating the case for Torre Pacheco, Murcia, Southeast of Spain,” Renew. Energy, 2014. [CrossRef]

7. Doddipati Srinath, Gomasa Ramesh, "Mechanical Properties of Sustainable Concrete by using RHA and Hydrated Lime", International Journal for Modern Trends in Science and Technology, Vol. 07, Issue 02, February 2021, pp.-83-86, DOI:10.46501/IJMTST0702014 [CrossRef]

8. Gopu Anil, Gomasa Ramesh and Dr. Annamalai Rangasamy Prakash, "An Experimental Study Investigation on Self Compacting Concrete and Strength Properties by using Fiber Reinforcement", International Journal for Modern Trends in Science and Technology, Vol. 07, Issue 02, February 2021, pp.-93-96, DOI: 10.46501/IJMTST07022016

9. R. L. Church and A. T. Murray, Business Site Selection, Location Analysis and GIS. 2008. [CrossRef]

10. SriramojuSravani, Gomasa Ramesh and Dr. G. Dinesh Kumar, "Study on Percentage Replacement of Cement by Glass powder for M20 Grade Concrete", International Journal for Modern Trends in Science and Technology, Vol. 07, Issue 02, February 2021, pp: 129-132, DOI:10.46501/IJMTST0702022

11. C. Te Tseng, S. C. Chen, C. S. Huang, and C. C. Liu, "GIS-assisted site selection for artificial reefs," Fish. Sci., 2001. [CrossRef]

12. Bandi Pooja, Gomasa Ramesh and Dr. G. Dinesh Kumar, "Experimental Study on Mechanical Properties of Geopolymer Concrete by using Fly Ash and RHA", International Journal for Modern Trends in Science and Technology, Vol. 07, Issue 02, February 2021, pp.-50-55, DOI:10.46501/IJMTST0702008

13. H. Yousefi, S. Ehara, and Y. Noorollahi, "Geothermal Potential Site Selection using GIS in Iran," Thirty-Second Work. Geotherm. Reserv. Eng., 2007.

14. Palakurthi Manoj Kumar, Gomasa Ramesh and Dr. Annamalai Rangasamy Prakash, "Evaluation of Different Tests and their Comparisons by Combining Cement with Various Binders", International Journal for Modern Trends in Science and Technology, Vol. 07, Issue 03, March 2021, pp.: 119-122, DOI: 10.46501/IJMTST0703021

15. Bonagani Vamshi Krishna, Gomasa Ramesh and Dr. Annamalai Rangasamy Prakash, "Effect of Geo-Activator on Strength and Durability Properties of Geopolymer Concrete", International Journal for Modern Trends in Science and Technology, Vol. 07, Issue 03, March 2021, pp.: 123-126, DOI:10.46501/IJMTST0703022

16. Gomasa Ramesh, Doddipati Srinath, Mandala Sheshu Kumar; "Earthquake Resistant of RCC Structures" Published in International Journal of Trend in Scientific Research and Development (ijtsrd), ISSN: 2456-6470, Volume-4, Issue-5, August 2020, pp.808-811.

17. M. Uyan, "GIS-based solar farms site selection using analytic hierarchy process (AHP) in Karapinar region Konya/Turkey," Renewable and Sustainable Energy Reviews. 2013. [CrossRef]

18. Gomasa Ramesh, Doddipati Srinath, Mandala Sheshu Kumar, "Importance of Dynamic Analysis for RCC Structures", International Journal for Modern Trends in Science and Technology, 6(8): 271-276, 2020, DOI:10.46501/IJMTST060844 [CrossRef]

19. S. M. Mokashi, "SITE SELECTION.," Chem. Age India, 1985

20. Gomasa Ramesh, D Srinath, "Repair, rehabilitation and retrofitting of reinforced concrete structures by using non-destructive testing methods", March 2021, Materials Today: Proceedings, DOI: $10.1016 /$ j.matpr.2021.02.778 [CrossRef]

21. Z. G. Rahmat et al., "Landfill site selection using GIS and AHP: a case study: Behbahan, Iran,” KSCE J. Civ. Eng., 2017. [CrossRef]

22. D Srinath, G Ramesh, "Mechanical properties of sustainable concrete by using RHA and hydrated lime", March 2021, Materials Today: Proceedings, DOI: 10.1016/j.matpr.2021.02.785 [CrossRef]

23. A. Rikalovic, I. Cosic, and D. Lazarevic, "GIS based multi-criteria analysis for industrial site selection," in Procedia Engineering, 2014. [CrossRef]

\section{AUTHORS PROFILE}

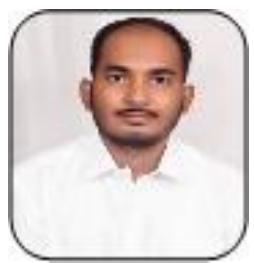

Mr. Gomasa Ramesh, B. Tech Civil Engineering, M.Tech Structural Engineering, Vaagdevi College of Engineering, Warangal, 506005, Telangana, India. Presented and Participated in various International conferences and as well as National Conferences and also Received Best Paper Awards for some Papers and also Received Best Young Researcher Award for 2020. Published more than 15+ Research Papers in International Peer Reviewed UGC Journals. Received Academic Excellence Awards from Andhra Pradesh Socia Welfare Residential School, Manthani during SSC-2011(School First) and also Received Academic Excellence Award from VMR Polytechnic, Diploma in Civil Engineering during 2014 (Class First) and also Received Academic Excellence Award from HITS, Hyderabad during 2017 (Class Second). Selected and Shortlisted for Site Engineer Position to Work with GHMC Housing Board of Telangana (Application Id:14517. Member of various Professional Bodies American Society of Civil Engineers, Structural Engineering Institute, Institute of Structural Engineering, American Concrete Institute and American Society of Testing Materials etc.

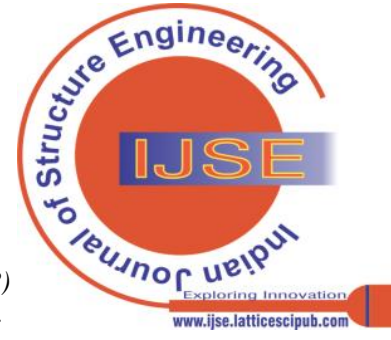

